\title{
Mõjuäng: luuleteooria. Clinamen ehk poeetiline väärlugemine ${ }^{1}$
} Harold Bloom

See lühike raamat sisaldab üht võimalikku luuleteooriat, mis on rajatud poeetilise mõju kirjeldusele või sisepoeetiliste suhete loole. Meie teoreetilise ettevõtmise esimene eesmärk on korrektiivne: deidealiseerida meie tavaarusaamad sellest, kuidas üks luuletaja aitab kujundada teist. Teine, samuti korrektiivne eesmärk johtub esimesest: luua poeetika, mis vastaks ning toetaks adekvaatsemat praktilist kriitikat.

Raamatus väidetakse, et luule ajalugu ei saa eristada poeetilisest mõjust, kuna luule ajaloo tegijad on tugevad luuletajad, kes loevad teineteist vääriti, et seeläbi vabastada oma kujutlusvõimele vajalikku imaginaarset ruumi.

Minu huviorbiidis on vaid tugevad luuletajad, need suurkujud, kellel jätkub vintskust rüseleda oma tugevate eelkäijatega, vajaduse korral surmani. Nõrgad talendid idealiseerivad, aga võimekad kujutlejad kasutavad enese otstarbeks ära. Igal asjal on aga oma hind, ning ka poeedi niisugune enesekujundamine toob kaasa mitmekülgset ängistust oma võlgnevuse pärast, sest ükski suur poeet ei soovi teadmiseks võtta, et ta pole olnud suuteline iseennast looma. /---/

Poeetilise mõju sügavused ei ole taandatavad ei allikakriitikale, ideede ajaloole ega kujundimustrite väljajoonistamisele. Poeetiline mõju - ehk see, mida ma käesolevas kirjutises sagedamini nimetan väärtõlgenduseks (misprision) - ei saa mööda vajadusest uurida looja elutsüklit loojana. Kui sellises uurimuses võetakse arvesse elutsükli läbimängimise tausta, siis seda tehakse kahel moel ja meetodil. Luuletajate omavahelisi suhteid luuletajatena käsitletakse esiteks juhtumianalüüsidena, mis sarnanevad Sigmund Freudi täheldatud „perekonnaromaanidega" (family romance), teiseks aga peatükkidena modernse revisionismi ajaloos - kusjuures "modernne” tähendab siin valgustusjärgset. Nagu Walter Jackson Bate näitab oma teoses „Mineviku koorem ja inglise luuletaja”, ${ }^{2}$ on modernse luuletaja vaimseks pärandiks melanhoolia, mis tuleneb Valgustusaja mõtlemise topeltskepsisest nii antiikaja kui ka renessansi meistritelt saadud kujutlusrikkuse aadressil. Käesolevas raamatus jätan Bate'i poolt oskuslikult käsitletud valdkonna kõrvale, keskendumaks sisepoeetilistele suhetele kui perekonnaromaani võrdkujudele. Ehkki võtan need võrdkujud kasutusele, teen seda mõningaid freudilikke rõhuasetusi sihilikult kohaldades.

1 Tõlge põhineb esmaväljaandel: Harold Bloom, „The Anxiety of Influence: A Theory of Poetry”. New York: Oxford University Press, 1973. (Siin ja edaspidi pärinevad joonealused märkused tôlkijalt. Täpsuse huvides on isikute esmamainimisel lisatud tõlkesse ka eesnimed, mida Bloom ise enamasti ei ole märkinud. Kõik rõhutused kursiivis pärinevad originaalist. Olulisemad mõisted ja väljendid on esitatud sulgudes originaalipäraselt.)

2 Walter Jackson Bate, „Mineviku koorem ja inglise luuletaja” ("The Burden of the Past and the English Poet”, 1970). 
Need kuus revisionistlikku võtet, mida tugeva luuletaja elutsükli puhul jälgin, ei tarvitse olla ainukesed, nende kogum ei pruugi olla võimalusi ammendav ning neile võiks ka hoopis teistsuguseid nimesid anda. Piirdusin kuuega, mis annavad minu arvates kokku miinimumi, ja need on ühtlasi kesksed argumendid, seletamaks, kuidas üks luuletaja teisest kõrvale kaldub. Kuigi nimetused võivad tunduda meelevaldsed, on neil siiski seoseid mitmete Lääne kujutluselus keskmesse asetunud traditsioonidega, ning ma loodan, et nad osutuvad kasulikuks.

Meie keele kõige suurem poeet jääb mitmel põhjusel käesoleva raamatu käsitlusalast välja. Neist esimene põhjus on kahtlemata ajalooline: William Shakespeare kuulub suurde veeuputuse-eelsesse ajastusse, tema looming sai teoks enne seda aega, mil mõjuäng (anxiety of influence) muutus poeetilise teadvuse jaoks keskseks probleemiks. ${ }^{3}$ Teine põhjus seisneb lüürilise ja dramaatilise vormi vahelises erinevuses. Mida subjektiivsemaks on muutunud luule, seda dominantsemaks on saanud eelkäijate varjud. Kuid peamine põhjus on asjaolu, et Shakespeare'i põhiline eelkäija oli Christopher Marlowe - luuletajana palju väiksem kui tema pärija. Kogu oma tugevusele vaatamata pidi John Milton subtiilselt, aga otsustavalt võitlema palju võimsama eelkäijaga, nimelt Edmund Spenseriga, ning see võitlus nii kujundas kui ka moondas teda. Samuel Taylor Coleridge, kes oli Miltoni ning hiljem ka William Wordsworthi efeeb, oleks olnud õnnelik, kui ta oleks William Cowperis leidnud oma Marlowe (ehk kui selleks oleks osutunud veel nõrgem William Lisle Bowles), kuid mõju pole otsustuse küsimus. Inglise keeles on Shakespeare markantseim näide nähtusest, mis jääb käesolevast käsitlusest välja: eelkäija täielik allaneelamine. Minu huvi piirdub võitlustega kahe tugeva võrdse vahel, kelleks on isa ja poeg kui võimsad vastased, Laios ja Oidipus ristteel, ent mööngem - ning see saab alljärgnevalt ka selgeks -, et mõned isad on koondkujud. Et isegi kõige tugevamad luuletajad alluvad mõjutustele, mis ei ole üksnes poeetilised, on isegi mulle endastmõistetav, kuid kordan, et minu huviorbiidis on vaid Iuuletaja Iuuletajas ehk aborigeenne poeetiline mina.

Muudatus, mida ma mõju mõiste suhtes ette panen, peaks aitama meid adekvaatsemalt lugeda mis tahes teineteisega kaasaegsete möödunud aegade luuletajate rühma. Näiteks kuulusid John Keatsi oma luuletustes vääriti tõlgendavate viktoriaanlike jüngrite hulka kindlasti Alfred Tennyson, Matthew Arnold, Gerard Manley Hopkins ning Christina Georgina Rossetti. Keegi ei saa absoluutse kindlusega väita, et Tennyson oma pikas, peidetud võistluses Keatsiga võitjaks jäi, kuid tema üleolek Arnoldist, Hopkinsist ja Rossettist tuleneb tema vähemalt osalisest võidust ehk iseendaks jäämisest võrreldes viimase kolme osaliste kaotustega. Arnoldi eleegiline luule segab kohmetult Keatsi-pärase stiili antiromantilise tundega, samas kui Hopkinsi pingutatud intensiivsused ning keeruline väljendusviis ja Rossetti inkrustatsioonidega küllastatud kunst on samuti ebakõlas nende vaevustega, mille leevendamist nad oma poeetiliste minade juures otsivad. Kui vaadata meie endi kaasaegseid, peaksime heitma

3 Eestikeelse vaste mõistele anxiety of influence (mõjuäng) pakkus Jaanus Adamson oma essees „Kriitika ja mõjuäng” (vt rmt „Läbirääkimised: kirjutisi 1995-2003”, 2004, Ik 51-67). 
värske pilgu Ezra Poundi lõputule võistlusele Robert Browninguga ning Wallace Stevensi pikale, suurel määral varjatud kodusõjale kõikide suuremate inglise ja ameerika romantiliste luuletajatega - Wordsworthi, Keatsi, Shelley, Emersoni, Whitmaniga. Nagu viktoriaanlike keatsiaanide puhul, osutavad needki näited võimalusele, et luule ajaloo kohta oleks nii mõnigi tõesem lugu rääkida. /---/

\section{Sünopsis: kuus revisionistlikku võtet ${ }^{4}$}

1. Clinamen - poeetiline väärlugemine ehk väärtõlgendus selle täpses ja otseses mõttes. Sõna tuleb Lucretiuselt, kelle teostes tähendab see aatomite „kõrvalekaldumist”, mis on mis tahes kosmilise muutusvõimaluse põhitingimuseks. Poeet kaldub oma eelkäija rajalt kõrvale, lugedes ühte oma eelkäija luuletust omaenda luuletuses nii, et sooritab esimese suhtes clinamen'i ehk korrektiivse pöörde. Sellega ta näitab, et eelkäija luuletus oli õigel teel, aga ainult teatud punktini, kus ka tema oleks pidanud kõrvale kalduma ning liikuma selle luuletuse suunas, mille hilisem luuletaja tegelikkuses kirjutas. ${ }^{5}$

2. Tessera - täideminek ja antitees. Ma ei võtnud seda sõna mitte mosaiigikunstist, kus ta praegu veel kasutusel on, vaid iidsete salasektide juurest, kus ta tähendas tunnusmärki, näiteks ühe väikese savipoti seda kildu, mis võimaldab teisi potikilde kokku panna, et anumat kui tervikstruktuuri rekonstrueerida. Poeet „täiustab” oma eelkäijat, lugedes vanem-luuletust nii, et selle tingimused (ehk koostisosad) jäävad alles, kuid tähendused muutuvad, justkui poleks eelkäija suutnud oma mõttes piisavalt kaugele minna.

3. Kenosis - katkestav võte, mis sarnaneb nende kaitsemehhanismidega, mida kohtame psüühikas kordamissunduste puhul; kenosis on eelkäija suhtes katkestava suunitlusega liigutus. Sõna võtan apostel Pauluselt, kelle jaoks kenosis märgib Jeesuse enesealandamist ja enesetühjendamist, kui viimane nõustub enese taandamisega jumalikust inimlikku staatusesse. Hilisem poeet, kes paistab end tühjendavat oma afflatus'est ehk ettekujutuslikust jumalikkusest, tundub end alandavat niivõrd, et lakkab otsekui üldse olemast poeet, kuid see hääbumine viiakse eelkäija hääbumispoeemi suhtes läbi niimoodi, et ka eelkäija ise paistab tühjenevat, nii et järeltuleva luuletuse tühjenemine ei osutu nii täielikuks, kui paistab.

4. Daemoniseerimine ehk liikumine isiklikustatud Vastu-Ülevuse suunas, reaktsioon eelkäija Ülevusele. Võtan mõiste neoplatonistide üldisest kasutusest, kus see märgib vahepealset olevust, ei jumalikku ega inimlikku, kes poeb salakunstimeistri sisimasse, et teda abistada. Hilisem luuletaja avab end väele, mida ta arvab olevat vanem-luuletuse vägi, mis ei kuulu varasemale luuletajale, vaid olemissfär̈ri, mis eelkäijat pisikese ülejäägi võrra ületab.

4 Originaalis on alliteratiivne six revisionary ratios.

5 Juba esimese ratio (revisionistliku võtte) käsitlusest on näha selle tautoloogilisus. Lugejale olgu siis hoiatuseks, et siin ei ole tegemist erinevate kategooriatega, ammugi mitte klassifikatsioonisüsteemiga, vaid „kõrvalekaldumise” variatsioonidega. 
Hilisem luuletaja saavutab selle toimingu oma luuletuse sisimas, seades end vanem- luuletusega sellisesse seosesse, et eelkäija töö unikaalsus lahtub üldistamise käigus.

5. Askees - enesepuhastamisliikumine, mille eesmärk on üksildusseisundi saavutamine. Nii üldine kui see mõiste ka ei tundu, võtan selle Empedoklese-sarnastelt eelsokraatlikelt šamaanidelt. Siin ei tühjenda hilisem poeet end revisionistlikult (nagu kenosis'es), vaid tõmbub tagasi, ohverdades ühe osa oma inimlikust andest ja kujutlusvõimekusest, et end teistest - ka oma eelkäijast - eraldada; ta paigutab oma luuletuse selle enese kaudu eelkäija luuletusega niisugusesse seosesse, et ka see luuletus läbib askeesi, kärpides nii ka eelkäija andekust.

6. Apophrades ehk surnute tagasitulek. Sõna tuleneb ateenlaste „viletsatest” ehk halva õnne päevadest, mil surnud tulid tagasi oma endistesse kodadesse elama. Oma Iõppfaasis tunneb hilisem luuletaja end olevat koormatud kujutlusvõimelisest üksildusest, mis läheneb peaaegu solipsismile. Ta hoiab omaenda luuletust eelkäija luulele taas nii avali, et esiotsa võib jääda mulje, nagu oleks ratas teinud täispöörde ning me oleksime jõudnud tagasi hilisema luuletaja üleujutatud õpipoisipõlve, hetke enne seda, mil tema jõud läbi revisionistlike võtete avalduma hakkas. Kuid kui varem oli luuletus avatud, siis nüüd hoitakse teda tahtlikult avatuna, ning lõpptulemusena (nii ebaõdus, kui see ka ei ole) ei lase uue luuletuse saavutus meile paista mitte seda, et selle oleks kirjutanud eelkäija, vaid seda, et hilisem poeet on ühtlasi kirjutanud ka eelkäijale iseloomulikud teosed.

\section{Esimene peatükk: clinamen ehk poeetiline väärtõlgendamine}

Noam Chomsky on täheldanud, et kui me mõnda keelt rääkida oskame, siis seeläbi omandame palju seesugust, mida me pole kunagi teadlikult õppinud. Kriitika pingutab selle nimel, et õpetada meile keelt, sest üks asi, mida pole kunagi õpitud, kuid mis tuleb keele enese kingitusena, on juba kirjutatud luule - selle mõttekäigu tuletan Shelley märkusest, et iga keel on relikt mahajäetud tsüklilisest luuletusest. Keel, mida kriitika meile õpetab, ei ole „kriitika oskuskeel" (see oleks formalistlik arusaam, mida ikka veel jagavad arhetüüpide-kriitikud, strukturalistid ja fenomenoloogid), vaid see keel, milles luule on juba (ära ja ette) kirjutatud, mõju ehk selle dialektika keel, mis valitseb luuletajate omavahelisi suhteid luuletajatena. Luuletaja, kes peitub igas lugejas, ei tunneta enda ja loetu vahel seda lõhet, mida igas lugejas peituv kriitik paratamatult kogeb. See, mis pakub naudingut lugejas peituvale kriitikule, võib tekitada temas peituvale poeedile ängi - ängi, millele lugejatena oleme omaenese kaoks või hädaohuks õppinud mitte tähelepanu pöörama. See äng, melanhoolia niisugune laad, on mõjuäng, sünge deemonite riik, mille pinnale vajutame peatselt oma esimese jälje.

Kuidas saavad inimestest poeedid, ehk, kui valida vanem sõnastus, kuidas kehastub inimesse poeetiline loomulaad? Kui potentsiaalne luuletaja avastab esimest korda mõju dialektika (või leiab see teda ise üles) - kui ta avastab esimest korda, et luule on ühtaegu nii väljaspool teda kui ka tema sees -, alustab ta protsessi, mis lõpeb alles ja ainuüksi siis, kui temas pole enam luuleraasugi järel; kaua pärast hetke, mil temas kaob võime (või iha) 
avastada luulet väljaspool end. Ehkki igasugune seda laadi avastamine on iseenda äratundmine, justkui Teine Sündimine, ning kuigi puhtteoreetiliselt peaks see äratundmine toimuma täiuslikus solipsismis, ei ole see toiming kunagi iseeneses täielik. See on Poeetiline Mõju teiste luuletajate pelga olemasolu imelise, painava ning nauditava teadvustamise läbi, nii nagu seda võib tunda peaaegu-et-täieliku solipsisti, potentsiaalselt tugeva poeedi sügavustes. Sest luuletaja on määratud teadvustama oma sügavamaid igatsusi tajumuses, et teised minad on olemas. Luuletus asub kusagil tema sees, aga ta peab ometi kogema seda häbi ja seda hiilgust, et temast väljaspool asuvad luuletused - suured luuletused - leiavad ta ise üles. Vabadusekaotus selles keskses ning põhilises mõttes ei ole teistele luuletajatele iialgi andestatav: tuleb õppida, et hirm oma ohustatud sõltumatuse ees on igavene.

André Malraux on öelnud, et „iga noore mehe süda on surnuaed, kuhu on raiutud tuhande surnud kunstniku nimed, kuid kus tegelikult leiavad eluaseme vaid paar võimsat, vastakat tonti." Ta lisab: „Luuletajat kummitab hääl, millega ta peab oma sõnad kooskõlla seadma." ${ }^{6}$ Kuna Malraux' enda huvikeskmes on visuaalsus ja narratiiv, tuletab ta oma väidetest valemi „pastišist stiilini”, kuid see ei kirjelda adekvaatselt poeetilist mõju, mille puhul kulgemine eneserealiseerimise suunas leiab täpsema sõnastuse Søren Kierkegaardi märksa drastilisemas lausungis: „See, kes on valmis tööd tegema, sünnitab omaenda isa.” Kui meenutame, kuidas mitmeid sajandeid - Homerose poegadest Ben Jonsoni poegadeni - kirjeldati poeetilist mõju isa ja poja vahelise suhte läbi, jõuamegi tõdemuseni, et jutt poeetilise pojasuse asemel poeetilisest mõjust on taas kord valgustusaja tulemus, veel üks kartesiaanliku dualismi aspekt.

Juba Aquino Thomase skolastiline ladina keel määratles mõju (influence) mõistet kui kindlat laadi „võimu teise üle”, kuid veel sajandeid ei kaotanud see oma juurtähendusena „sissevoolamist” ega peatähendusena „tähtedest inimkonna peale kiirgavat väge või emanatsiooni”. "Olla mõjutatud” tähendas algkasutuses võtta vastu tähtedest inimese peale voogavat õhulist fluidumit, mis oli suuteline kujundama iseloomu, saatust ning kõiki teisi asjaolusid päikese all. See taevalik ja moraalne, hiljem lihtsalt salajane vägi avaldas end vaatamata kõigele sellele, mida varem peeti vaba tahte pärusmaaks. Tähendus, mille anname „mõjule” poeetilist mõju silmas pidades, on väga hiljutine. Inglise keele ajaloos ei kuulu see veel John Drydeni kriitilisse sõnavarasse ega kasuta seda meie tähenduses ka Alexander Pope. 1755. aastal eristab Samuel Johnson mõju mõistet, määratledes selle astraalset ja moraalset aspekti, öeldes viimase kohta, et see on „tõusujõud” (Ascendant power), „võime midagi juhtida ja muuta", kuid ta toob näiteid üksnes religioossest või isiklikust, aga mitte

6 André Malraux (1901-1976) on prantsuse kirjanik, keda tuntakse peamiselt tema 1933. aastal Prix Goncourtiga pärjatud romaani „Inimese saatus” („La condition humaine”) kaudu, mis käsitleb ebaõnnestunud kommunistlikku vastuhakku Shanghais. Bloomi viide Malraux'le on pärit tema vähe tuntud kolmeköitelisest teosest „La psychologie de l'art” (1947-1949), mis avaldati hiljem üheköitelise raamatuna, mille uueks pealkirjaks sai „Vaikuse hääled” („Les voix du silence”, 1953). Üks teose põhiväiteid on, et kunstil on esteetilise mõnuga vähe tegemist. 
kirjanduslikust vallast. Aga juba kaks põlvkonda hiljem, Coleridge'i jaoks, on mõju mõiste omandanud kirjanduslikus kontekstis enam-vähem siin kasutatava tähenduse.

Kuid äng oli olemas ammu enne „mõju” praegust kasutust. Ajavahemikus, mis Ben Jonsonit Samuel Johnsonist eraldas, oli luuletajatevahelisest pojalikust lojaalsusest saanud keerulisem tunnetelabürint, mida Freud nimetas esmalt ja vaimukalt „perekonnaromaaniks”, samas kui moraalsest võimust oli saanud hoopis melanhoolia pärusmaa. Veel Ben Jonson näeb mõjus midagi tervislikku. Järeleaimamise (imitation) kohta ütleb Jonson, et see on „võime konverteerida teise luuletaja substantsi ja rikkust omatarviduspäraseks. Valida üks hiilgav mees kõikide teiste hulgast ning käia tema järel seni, kuni muutud nii tema sarnaseks, nii temaks, et koopia võib eksikombel algupärandiga ära vahetada." Järelikult ei tekita järeleaimamine Ben Jonsonis mingit ängi, kuna temale (värskendav mõte!) on kunst raske töö. Kuid vari langes ning valgustusaja-järgse Geeniuse ja Ülevuse kirega tuli kaasa äng, sest siis peeti kunsti juba millekski enamaks kui raskeks tööks. Edward Young, pidades longiniaanlikult lugu Geeniusest, juurdleb poeetiliste esiisade kahjulike vooruste üle ning otsekui ennetab John Keatsi kirju ja Ralph Waldo Emersoni traktaati eneseusaldusest, kui leinab oma suuri eelkäijaid: „Nad köidavad meie tähelepanu, takistades meid endid korralikult läbi katsumast; nad kallutavad meid nende võimeid enda omadest kõrgemaks pidama, vähendades meie väärtust; nad hirmutavad meid oma kuulsuse säraga." Dr Samuel Johnson, toekam mees, kelle antiigitruudus oli veelgi sügavam, Iõi sellele vaatamata kompleksse kriitilise maatriksi, milles lodevuse, üksilduse, originaalsuse, järeleaimamise (ning välmingu) mõisted on kõige kummalisemal kombel segamini paisatud. Johnson haugatas: „Mis puutus poeetilisse karistusse, siis Tantalose juhtum oli ju mõneti haletsusväärne, kuna teda ümbritsevad viljad lausa tõmbusid ta kätest eemale; aga millisele hellusele võivad loota need, kes küll enda arvates põevad Tantalose piinasid, kuid ei tõsta iseenda valu leevendamiseks sõrmegi?" Johnsoni haukumise peale võpatame meiegi, võpatame seda enam, kuna me teame, et ta räägib samas ka iseendast, sest luuletajana oli ta teine Tantalos, järjekordne Katva Keerubi ohver. ${ }^{7}$ Kui nii võtta, siis pääsevad vaid Shakespeare ja Milton peksupingist: Johnsoni hukkamõist tabas isegi Vergiliust, kes olevat liigagi vaid Homerose järeleaimaja. Johnsoni, meie keele kõige suurema kriitiku näol kohtume niisiis esimese diagnostikuga, kes tabab ära poeetilise mõju haiguse. Kuid see diagnoos kuulub tema ajastu juurde. David Hume, kes imetles Edmund Wallerit, arvas, et Wallerit päästab tema distants Horatiusest. Meie, kes me oleme ajas veel edasi, tajume, et Waller siiski polnud Horatiusest piisavalt kaugel. Waller on surnud,

7 Varjav ehk Kattev Keerub (Covering Cherub) on Miltoni „Kaotatud paradiisi” tegelane. Bloom laenab selle mõiste William Blake'i poeetilisest leksikonist, kus see on Blake'i märksõna Miltoni jaoks, kes oli tema kõige tugevam poeetiline eelkäija. Intertekstuaalselt aga ulatub Varjav Keerub tagasi Esimese Moosese raamatu pattulangemise Iooni (1 Mo 3:24). Pärast pattu teinud inimeste väljaheitmist paradiisiaiast pannakse Eedeni aia idapoolsele servale valvama keerubid oma leegitseva, pöörleva mõõgaga, et takistada teed Elupuu juurde. Varjav Keerub on üks neist, kes valvab ligipääsu Elupuu juurde. 
Horatius aga elab edasi. „Valitsuse koorem,” juurdleb Johnson süngelt, „lasub nende otseste eelkäijate tõttu printside õlgadel raskemalt," ning lisab: „samasuguste raskustega peab arvestama kuulsa kirjaniku järglane." ${ }^{8}$ See pehkinud huumor on meilegi tuttav: iga lugeja, kes on kogenud Norman Maileri „Reklaame iseendale” („Advertisments for Myself”), tunneks mõnu neist pöörastest tantsudest, millega ta püüab oma ängi vältida, ängi, mis on läbi ja lõhki Ernest Hemingwayst tingitud. Vähem meelepärane on läbi lugeda Theodore Roethke „Kauge põld” („The Far Field”) või John Allyn Berrymani „Ta lelu, ta uni, ta rahu” („His Toy, His Dream, His Rest") ning avastada, et Roethke põld asub Whitmani, Elioti, Stevensi ning Yeatsi omadele liiga lähedal ja et Berrymani lelu, unenägu ning tõeline rahu on lohutanud neidsamu luuletajaid. Meie jaoks on mõju seesama äng, mis ta oli Johnsonile või Hume'ile, kuid nii nagu võimendub meie loo paatos, väheneb ka selle väärikus.

Ajapikku on Poeetilisest Mõjust saanud osa tunduvalt laiemast nähtusest, mida nimetame intellektuaalseks revisionismiks. ${ }^{9}$ Meie ajal on revisionism oma olemust muutnud - olgu siis poliitilise teooria, psühholoogia, teoloogia, õiguse või poeetika vallas. Revisionismi eellane on ketserlus, mis pigem timmis doktriini tasakaalu, kui tegi selles loomingulisi parandusi viimast võiks aga pidada modernse revisionismi isikupäraks ja tunnusmärgiks. Ketserlus päädis üldjuhul muudatusega rõhuasetuses; revisionism läheb aga aktsepteeritud doktriiniga teatud punktini kaasa, kuid teeb siis kõrvalekalde ${ }^{10}$, nõutades, et doktriinis tekkis eksitus just täpselt selles kohas ning ei kusagil mujal. Freud, kellel oli tegu oma revisionistide vaoshoidmisega, pomises: „On ainult vaja mõelda nendele jõulistele emotsionaalsetele teguritele, mis muudavad inimestel keeruliseks teistega kokku sobitumise või neile allumise," kuid Freud ise oli liiga taktitundeline, et neid „jõulisi emotsionaalseid tegureid” analüüsida.

William Blake, kes oli sellisest taktitundelisusest rõõmsameelselt prii, on valgustusajast saadik kõige sügavam ja originaalsem revisionismiteoreetik ning seega ka vältimatu abimees uue Poeetilise Mõju teooria arendamisel. Olla mis tahes eelkäija süsteemi ori ei tähenda Blake'i jaoks midagi muud kui olla loominguliselt blokeeritud, olla kammitsetud omaenda loomingu kinnismõttelisest võrdlemisest oletatavalt eelkäija omaga. Poeetiline Mõju on eneseteadvuse haigus; ent isegi Blake ei jäänud ilma oma osakesest selles ängis. See, mis teda painas - terve pahede nimekiri -, jõudis talle võimsaimalt pärale nägemuses oma kõige suuremast eelkäijast:

8 Siin matkib Johnson Jesaja raamatu retoorikat.

9 Revisionismi kohta Bloomi teostes leidub sügavam käsitlus Jean-Pierre Mileuri monograafias „Kirjanduslik revisionism ja modernsuse koorem” („Literary Revisionism and the Burden of Modernity”, 1985).

10 Siinkohal kasutab Bloom veel sõna kõrvalekalle (deviation), viivitades veel oma lemmiksõna clinamen'iga väljaastumist. 
...the Male-Females, the Dragon Forms

Religion hid in War, a Dragon red \& hidden Harlot,

All these are seen in Milton's Shadow, who is the Covering Cherub... ${ }^{11}$

Nagu Blake, teame meiegi, et Poeetiline Mõju kujutab endast ühtaegu nii kasu kui ka kadu, mis on ajaloo labürindis teineteisest lahutamatult läbi põimunud. Aga mis on selles kätkeva kasu loomus? Blake eristas Seisundeid (States) ja Indiviide (Individuals). Indiviidid läbisid Olemise Seisundeid (States of Being), jäädes siiski Indiviidideks; Seisundid aga olid alalises muutumises, pidevas nihkumises. Üksnes Seisundid kandsid süüd, Indiviidid aga mitte kunagi. Poeetiline Mõju on Indiviidide või Partikulaaride kulgemine läbi Olemise Seisundite. Nagu revisionismi puhul ikka, on Poeetiline Mõju vaimne kingitus, mis jõuab meieni üksnes läbi selle, mida võiks kiretult kutsuda vaimu perverssuseks, või läbi Seisundite perverssuse (kui kasutada Blake'i täpsemat määratlust).

Küll aga võib mõnikord juhtuda, et üks luuletaja mõjutab teist, või täpsemalt öeldes, et ühe luuletaja luuletused mõjutavad teise luuletusi vaimse helduse, isegi vastastikuse helduse märgi all. Aga meie kergemeelne idealism ei pea siin paika. Kui mängus on heldus, siis luuletajad, keda heldelt mõjutatakse, on väiksemad või nõrgemad; mida rohkem on heldust ja mida vastastikusem see on, seda vaesemate luuletajatega on tegemist. Ning ka siin kandub mõju pigem läbi väärtajumuse, ehkki see kipub olema mittesihilik ja peaaegu alateadlik. Siinkohal jõuangi oma argumendi keskse põhimõtte juurde, mis võib küll tunduda vägivaldse ning ülekohtusena, kuid tema piisavat tõeväärtust see asjaolu ei kasvata ega kahanda:

Kahe tugeva, algupärase Iuuletaja puhul toimib Poeetiline Mõju alati esimese luuletaja vääriti lugemise kaudu hilisema poolt kreatiivse korrektsiooni teona, mis on tegelikult ja paratamatult väärtõlgendus. ${ }^{12}$ Viljaka poeetilise mõju ajalugu, mis tegelikult võrdubki Lääne luule keskse traditsiooniga renessansist saadik, on ängi ajalugu, karikeeriva enesepäästmise, väänamise ja perversse tahtejõulise revisionismi lugu, milleta modernset luulet ei oleks sellisel kujul saanud eksisteerida.

Minu isiklik Küsitlev Idioot, kes on end minu olemuse labürindi sisimasse kerra keeranud, hakkab siin kohe vastu vaidlema: „Mis kasu on sellisest põhimõttest, olgu temale tuginev argument tõene või mitte?" Kas on kasulik, kui meile öeldakse, et luuletajad ei ole tava-

11 Need Blake'i read jäägu tõlkimata. Värsid osutavad, et apokalüptilised (mõneti kimäärsed) kujud seisavad kõik Miltoni varjus. Milton ongi Kattev (Varjav) Keerub ise.

12 Jaanus Adamson kasutab siin vastet esimus, mis on kooskõlas Bloomi mõiste autoriteet eripärase nüansiga. 
lugejad (common readers) ${ }^{13}$, liiatigi veel mitte kriitikud, kes tegelikult pole muud kui kõige võimelisemad tavalugejad? Ja mis see Poeetiline Mõju siis õieti on? Kas selle uurimine saab olla midagi muud kui allikate jälitamise tüütu usinus, vihjete loetlemine, usinus, mis niikuinii teeb teadlastelt arvutitele üle kandudes läbi apokalüpsise? ${ }^{14}$ Kas see pole mitte Thomas Stearns Eliotilt pärinev klišee, et hea luuletaja varastab, kuid nõrk luuletaja reedab mõjutust, laenab endale hääle? Kas pole kõik kirjanduskriitika Suured Idealistid olnud poeetilise mõju eitajad, alustades Emersoni maksiimidest „Nõudke iseendid; ärge kunagi imiteerige” ja „Inimhing iialgi ei suvatse end korrata” ning Iõpetades Northrop Fryega, kellest on saanud meie aja Arnold ${ }^{15}$ ning kes rõhutab, et Hoolimise Müüt (Myth of Concern) takistab luuletajaid kannatamast oma võlgnevusest tulenevat ängi?

Vastuväitena sellisele idealismile võib tsiteerida Georg Christoph Lichtenbergi rõõmsameelset märkust: „Mulle samuti meeldib imetleda suurmehi, kuid ainult neid, kelle teoseid ma ei mõista." Või siis taas kord vahendades Lichtenbergi, kes on üks Poeetilise Mõju mõttetarku: „Teha vastupidist on vaid veel üks järeleaimamise vormidest, ning järeleaimamise definitsioon peaks õigupoolest hõlmama mõlemat." Lichtenberg osutab Poeetilise Mõju oksüümoronlikkusele, ja selles on tal muidugi õigus. Kuid teisalt on ka Romantiline Armastus oksüümoron, ning Romantiline Armastus on Poeetilise Mõju kõige lähem analoogia - imeline, ehkki täpselt vastassuunas liikuv vaimuperverssus. Poeet, kes peab vastu seisma oma Suurele Algupärandile, peab selles üles otsima olematu hälbe, mis asub eelkäija kõrgeima kujutlusvõimelisuse vooruse südames. Armastaja on meelitatud kaotuse südamesse, kuid leiab end, nagu ta peagi avastab, vastastikusest illusioonist, olematust luuletusest. „Kui kaks inimest teineteisesse armuvad," ütleb Kierkegaard, „ning kui nad hakkavad tunnetama, et nad on teineteise jaoks loodud, siis on käes hetk, mil nad peaksid oma suhte katkestama, sest edasi minnes on neil võimalik vaid kõik kaotada ja mitte midagi võita." Kui Suur

13 Mõiste common reader jõuab Bloomi kaudu lugejani graatsilise intertekstide kasutuse kaudu. Nagu seda omakorda osutab Virginia Woolf oma esseekogumiku „Tavalugeja” („The Common Reader”, 1925) eessõnas, kasutas Samuel Johnson seda mõistet oma Thomas Gray eluloos („Life of Gray”, 1780), tähistamaks seda lugejat, kes ei ole ei kriitik ega õpetlane, vaid on saanud mõlemaga võrreldes puudulikuma hariduse. Tavalugeja loeb oma naudinguks, mitte selleks, et vahendada teadmisi või teiste arvamusi korrigeerida. Johnson väidab: „I rejoice to concur with the common reader; for by the common sense of readers, uncorrupted by literary prejudices, after all the refinements of subtilty and the dogmatism of learning, must be finally decided all claim to poetical honours." Woolf jätkab tavalugeja iseloomustamist Johnsoni vaimus - ning vaimukalt: „Above all, he is guided by an instinct to create for himself, out of whatever odds and ends he can come by, some kind of whole - a portrait of a man, a sketch of an age, a theory of the art of writing. He never ceases, as he reads, to run up some rickety and ramshackle fabric which shall give him the temporary satisfaction of looking sufficiently like the real object to allow of affection, laughter, and argument." (Ik xi).

14 See tähendab, et nii positivistlik kui ka formalistlik kirjandusteadus on siin löögi all. Bloom ei taotle ei faktoloogilist kirjanduskriitikat ega ka „uuskriitikat” Elioti stiilis.

15 Northrop Frye kui meie aja Arnold viitab Viktoria-aegsele konservatiivsele kriitikule Matthew Arnoldile, keda peeti hea maitse kohtunikuks. 
Algupärand avastab efeebi, noormehe kui viriilse luuletaja figuuri, on efeebil aeg edeneda, sest siis on kõik tema päralt, samas kui tema eelkäijal pole ka midagi kaotada - seda muidugi juhul, kui end täiesti lahtikirjutanud luuletajad on tõepoolest „teispool kaotust”.

Kuid on olemas ka Seisund nimega Saatan, ning selles rängas olukorras peavad poeedid enda omaksvõtmisega ise toime tulema. Sest Saatan on niisuguse mina puhas ehk absoluutne teadvustus, mis on sundinud end üles tunnistama, et on astunud intiimsesse liitu opaaksusega. Saatana seisund on seega püsiv dualismiteadvus, teadmine, et ollakse mitte ainult ruumi (keha), vaid ka kellaga mõõdetava aja vangis. Olla puhas vaim, kuid tunda endas opaaksuse piire; väita, et kuigi olid olemas enne Loomist ja Pattulangemist, pead alistuma arvule, kaalule ja mõõdule: sellises lähteolukorras on Tugev Poeet, vägev kujutlusvõime, kui ta seisab vastamisi luulekõiksusega, kõikide olnud ja tulevate sõnadega, kultuuripärandi hirmuäratava hiilgusega. Meie ajal on see olukord veelgi meeleheitlikum kui 18. sajandil, mil kõikjal kummitas Milton, või 19. sajandil, mil kummitas Wordsworth, ning meie praegustele ja tulevastele poeetidele on lohutuseks vaid see, et Miltoni ja Wordsworthi ajast saadik pole tõusnud ühtegi Titaanlikku kuju - ka mitte Yeats ega Stevens.

Kui vaatleme lähemalt neid tosinat suurt poeetilist mõjutajat enne käesolevat sajandit, ei kulu palju aega, enne kui avastame, kes nende hulgas on Suur Vastane, see Sfinks, kes isegi tugevad kujutlusvõimed juba hällis ära kägistab - Milton. See oli Keats, kes võttis resoluutselt kokku inglise luule olukorra pärast Miltonit: „See, mis temale elu, oleks minule surm.” Miltoni surmav vitaalsus on tema Saatana-seisund, mida ei näita mitte niivõrd Saatan kui tegelane tema „Kaotatud paradiisis”, kuivõrd Miltoni enda justkui kommenteeriv suhe omaenda Saatanaga, ning tema suhe kõikide tugevate poeetidega, nii 18. sajandi kui ka enamiku 19. sajandi omadega.

Milton on keskseks probleemiks iga võimaliku ingliskeelse poeetilise mõju teooria ning ajaloo jaoks, rohkem veel kui Wordsworth, kes seisab nii meile kui ka Keatsile lähemal ning kes seab meid vastamisi kõigega, mis on moodsas luules kõige problemaatilisem, see tähendab kõigega, mis on problemaatilisim meis endis. Seda sugulusliini, mille esivanemaks on Milton, suureks revisionistiks Wordsworth ning sõltuvateks pärijateks teiste hulgas Keats ja Wallace Stephens, hoiab koos aus leppimine dualismi tegelikkusega ning loobumine ihast metsiku tahtejõuga kõiki dualisme ületada - ihast, mis domineerib visionäärsusse ja prohvetlikkusse kalduvate poeetide liinil alates Spenseri leebemast temperamendist ja lõpetades Blake'i, Shelley, Browningi, Whitmani või Yeatsi erinevate raevukustega. /---/16

Miltoni jaoks põhines kogu pattulangemise kogemus kaotusel ning paradiisi sai tagasi võita üksnes Üks Suurem Mees ja ei ükski poeet. Sellegipoolest pihib Milton John Drydenile, et tema enda Suur Algupärand oli Spenser, kes „The Faerie Queene'i” VI raamatus Iubab oma Colinile vähemalt Poeedi Paradiisi. Nii Johnson kui ka William Hazlitt rõhutavad, et erinevalt 
kõikidest oma järglastest oli Milton ainus, kes ei olnud võimeline mõjuängi olemasolu taluma. Johnson väitis resoluutselt, et kõikide nende hulgas, kes Homeroselt midagi laenasid, jäi Milton talle kõige vähem võlgu: „Ta oli loomu poolest isemõtleja, kindel oma võimetes ning põlastas nii abi kui ka takistusi: mitte et talle poleks oma eelkäijate mõtted ja kujundid korda läinud, ent ise ta neid taga ei otsinud." Ühes oma loengus, mille kuulajaskonda sattunud Keats sai sealt mõjutusi oma hilisema Negatiivse Võimelisuse (Negative Capability) mõiste loomiseks, kommenteeris Hazlitt Miltoni positiivset võimelisust (positive capability) oma eelkäijaid alla neelata: „Tema teoseid lugedes tunneme end võimsa intellekti mõju all: mida enam ta teistele läheneb, seda selgejoonelisema ja omanäolisemana ta end neist eraldab." Niisiis oleme sunnitud edasi küsima, mida Milton mõtles, kui nimetas Spenserit oma Suureks Algupärandiks. Vähemasti järgmist: Miltoni Teine Sündimine oli taassünd Spenseri romansimaailma. Ja kuna Milton pidas Spenseri romansimaailma terviklikuks illusiooniks, alistus ta seda enda jaoks asendades dualismi tegelikkusele kui olemise valule. Alles jäi tunnetus Spenserist kui tema Teisest - unenägu Teisesusest, mida kõik poeedid peavad kogema. Jättes maha oma nooruspõlve ühtsed ja ainulised püüdlused, Milton justkui sigitas selle luule, mida nimetame valgustus(aja)järgseks ehk romantiliseks, selle luule, mille kinnismõte on vaimu võim surmariigi üle, või - kui kasutada Wordsworthi sõnu - küsimus, millise määrani vaim on suveräänne isand ning meeled tema tahte teenrid. ${ }^{17}$

Ükski moodne luuletaja ei ole ühtne ega terviklik, vaatamata põhimõtetele, mida ta maailmale kuulutab. Moodsad poeedid on paratamatult armetud dualistid, sest nende viletsus ja vaesus on nende kunsti algpunkt - Stevensil on õigus, kui ta räägib „vaeste ja surnute sügavast luulest”. Luule võib küll „ühes mehes” lunastust tekitada, kuid lunastus tuleb ainult neile, kelle kujutlusvõimekus seda hädasti vajab, ning ka siis võib-olla hoopis kabuhirmu kujul. Seda lunastusnälga õpetab noorele poeedile ehk efeebile esmalt kogemus teisest poeedist, kogemus Teisest, kelle ülbe suurus võimendub efeebi nägemuses temast kui pimedusest ümbritsetud põlevast hiilgusest. Nii näeb Blake'i Kogemuse Laulik Tiigrit, liob oma Leviathanit või Behemothi, Ahab oma Valget Vaala, prohvet Hesekiel Varjavat Keerubit ${ }^{18}$ - kõik need

17 William Wordsworthi sõnad originaalis kõlavad järgmiselt: „To what extent the mind is lord and master, outward sense the servant of her will."

18 Siinkohal mõningad täpsustavad viited: William Blake’i luuletus „Tiiger” („The Tyger”) algab sõnadega „Tiiger! Tiiger! Loitma lööd / eredalt kesk laante ööd." (tõlk J. Talvet); laevakapten Ahab on tegelane Herman Melville'i teosest „Moby-Dick” (1851); Varjav Keerub osutab siin Piiblile (Hs 28:14-16). Prohvetite diskursus tõstab Moosese raamatute topos'ed kõrgemale astmele - nii sümboolselt kui ka tõlgenduslikult. Bloom lisab paar lehekülge pärast eelnevat mõttearendust Hesekieli seletusele juudi (rabide) Piibli-eksegeesi. Rabi Rashi järgi on Varjav Keerub mimshach (kaugeleulatav), see, kes on kõndinud kividel edasi-tagasi keset tulelõõma. Varjavad Keerubid, kes on rabinistliku traditsiooni kohaselt võrdsed hävitusinglitega, tähistasid Jumala hirmsat kohalolu. Kaasates inglise luuletraditsiooni kõrvale nüüd rabinistliku Piibli-tõlgenduse, arendab Bloom väga kõrgelennulist ning sügavale kaevuvat isikupärast eksegeesi. Intertekstide intuitiivne põimumine teeb tema enda teksti niivõrd tihedaks ja hermeetiliseks, et see on isegi traditsioonitundlikule lugejale raske jälgida. 
on nägemused Loodusest, millest on saanud kuri lõks, hiilgusest, mis ähvardab prometheuslikku Otsijat, kelleks peab iga efeeb peatselt saama. /---/19

Blake'i „lühieeposes” pealkirjaga „Milton” seisab Varjav Keerub end täiuslikult teostanud Mehe (kes on ühtaegu Milton, Blake ja Los) ning emanatsiooni ehk armastatu vahel. Kuid Blake'i „Jeruusalemmas” on Keerub tõkestav kuju, kes seisab Blake'i-Losi ja Jeesuse vahel. Kui küsida, keda või mida Keerub „varjab”, siis vastus oleks: Blake'i loomingus kõike seda, mida mõeldakse Looduse all; /---/ Esimeses Moosese raamatus Idaväravat, teed Elupuu juurde, kuid niisugusel blake'ilikul paradoksaalsel moel, et näib ise olevat see küllus. ${ }^{20}$

Seega - kas Varjav Keerub eraldab? Ei - tal pole seda võimu. Poeetiline Mõju ei ole niivõrd eraldumine, kuivõrd ohvriks tegemine - iha hävitamine. Poeetilise Mõju embleemiks on Varjav Keerub, sest ta sümboliseerib mateeria ulatuvuse kartesiaanlikku kategooriat. Ei ole sugugi juhuslik, et René Descartes oma mõttekaaslaste ja jüngritega on romantilises traditsioonis poeetilise nägemuse põlisvaenlane, sest kartesiaanlik ekstensiivsus kui kategooria on modernse dualismi, meie ja objekti vahelise peadpööritavalt sügava kuristiku juur. Descartes nägi objekte kui lokaliseeritud ruume; romantilise nägemuse iroonia seisneb aga selles, et mässati Descartesi vastu, ent ei viidud oma mässu küllalt kaugele (välja arvatud Blake): nii Wordsworth kui ka Freud jäävad kartesiaanlikeks dualistideks, kellele olevik on sadestunud minevik ning loodus on ruumi lokaliseeringute kontiinuum. Need kartesiaanlikud aja ja ruumi reduktsioonid kutsusid meile kaela poeetilise mõju negatiivse aspekti tõve, päästsid valla kirjandusliku influenza sissevoolava ängi epideemia kujul. /---/

Samas ei eksisteeri otsest kartesiaanlikku vimma ega eelarvamust poeetide vastu, ega leidu selles mõtlemises ka mingit analoogiat platonistliku poleemikaga nende autoriteedi vastu. Descartes kirjutas oma „Privaatsetes mõtisklustes” isegi järgmist: „Võib tunduda veidrana, et kaalukaid arvamusi leidub pigem poeetide kui filosoofide teostes. Põhjus on selles, et poeedid kirjutasid vaimustusest ning kujutlusvõimest lähtudes; meis kõigis leidub teadmise seemneid, nagu ränikivis peitub sädemeid; filosoofid ekstraheerivad need mõistuse kaudu, kuid poeedid raiuvad neid välja kujutlusvõime kaudu, mistõttu nemad säravad eredamalt." Siiski võttis kartesiaanlik müüt või teadvuse kuristik ränikivilt tuld ning vangistas poeedid olekusse, mida Blake nimetab „lõhestatud fiktsiooniks” (cloven fiction) - kahe antipoeetilise võimaluse, Idealismi ja Materialismi vahele. Filosoofia uhtus enesepuhastuses selle suure dualismi minema, kuid terve suurpoeetide liin Miltonist Yeatsi ja Stevensini oli võimeline kuulma vaid oma traditsiooni, Poeetilise Mõju kaja, mis jutustas neile, et „nii Idealism kui ka

19 Tõlkes on tehtud kärbe originaali Ik 35 kolmandast lõigust kuni Ik 38 esimese lõiguni.

20 Selles lõigus hakkab Bloom mängima mõiste covering (Cherub) teiste tähendusvarjunditega - covering tähenduses „katmine” ja „hõlmamine” võimaldab tal kavalalt ühte sulatada filosoofilised ning poeetilised kategooriad. Nagu järgnevas mõttearenduses selgub, püüab Poeet ehk loominguline isik katkestada kõikehõlmavust, rebida end lahti mateeria ekstensiivsusest, mille vangina ta end tunneb. 
Materialism on vastused sobimatule küsimusele". Nagu Descartes (või Wordsworth), pidid ka Yeats ja Stevens vaeva nägema, et saada nägijaiks mitte üksnes ihulise silmaga, vaid ka vaimus; Blake, ainuke tõeline antikartesiaan, leidis, et seegi vaev on „lõhestatud fiktsioon”, ning pilkas Kartesiaanlikku Dioptrikat, seades selle Mehhanisti vastu oma Pöörise. /---/

Blake ei soovi fenomene päästa ega järgneda nende pikale reale, kes koos Owen Barfieldiga soovivad (kui jäljendada Miltoni fraasi) „väliseid kujusid päästa”. ${ }^{21}$ Blake on Poeetilise Mõju lunastava ehk revisionistliku aspekti teoreetik, kelle impulsiks on püüda Varjavat Keerubit pagendada, seada ta tulistele kividele kõndima.

Kuna prantsuse visionäärid seisid Descartesi lummusele, Kartesiaanlikule Sireenile niivõrd lähedal, töötasid nad hoopis teises vaimus - kõrgetasemelise ning tõsise huumoriga, apokalüptilise irooniaga, mis kulmineerub Alfred Jarry ning tema jüngrite loomingus. Poeetilise Mõju uurimine on paratamatult üks Patafüüsika haru, ja ta tunnistab rõõmsalt üles oma võlgnevuse „...tõelisele Teadusele, mis koosneb Imaginaarsetest Lahendustest”. Kui Blake'i Los langeb Urizeni, meister-kartesiaani mõju all mürisedes alla Loomises-Langemises, siis teeb ta kórvalekalde, ning see Lucretiuse clinamen'i paroodia, see üleminek saatuselt kergele kapriisile ongi lõplikus iroonias kogu Urizeni-tüüpi loovuse individuaalsuse, kogu kartesiaanliku nägemuse kui niisuguse määr. Seesama clinamen ehk kõrvalekaldumine /---/ on tingimata Poeetilise Mõju teooria keskne mõiste, sest see, mis eraldab igat poeeti tema Poeetilisest Isast (ning päästab ta selle eraldamise kaudu), on loomingulise revisionismi juhtum. /---/ Poeet seab oma eelkäija enda jaoks niisugusesse asendisse, vangerdab tema taustal nii, et nägemuse objektid kaovad oma kõrgemas intensiivsuses kontiinuumisse ära. /---/ Kui loominguline tõlgendus on seega paratamatult väärtõlgendus, siis peame seda näilist absurdsust aktsepteerima. See on kõige kõrgema kraadi absurdsus - Jarry apokalüptiline absurd või see, mis kehtib Blake'i terve ettevõtmise kohta.

Teeme siis dialektilise hüppe: enamik „akuraatseid” luule tôlgendusi on veel midagi palju hullemat kui eksitused: ehk eksisteerivadki üksnes rohkem või vähem loomingulised või huvitavad eksilugemised, sest kas pole iga lugemine paratamatult clinamen? Ning kas me ei peaks sellessamas vaimus püüdma uuendada luule uurimist, tulles selle aluste juurde tagasi? Ühelgi luuletusel pole „allikaid” ning ükski luuletus ei „vihja” pelgalt teisele. Luuletusi kirjutavad mehed, ${ }^{22}$ mitte anonüümsed Hiilgused. Mida kangem mees, seda võimsamad ta vimmad ja seda ülbem tema clinamen. Kuid millise hinnaga peaksime meie lugejatena oma clinamen'ist loobuma?

Ma ei paku välja mitte uut poeetikat, vaid täiesti teistsugust praktilist kriitikat. Loobugem läbikukkunud ettevõtmisest „mõista” üksikut luuletust asjana iseeneses. Selle asemel

21 Owen Barfield - vt „Saatesõna tõlkele”.

22 „Mehed” on otsekoheselt ja androtsentriliselt öeldud. Bloomi „seksismi” kohta vt „Saatesõna tõlkele”. 
püüdkem õppida lugema luuletust tema autori kui poeedi eelkäija luuletuse ${ }^{23}$ või luule kui niisuguse sihiliku väärtõlgendusena. Tunne igat luuletust tema clinamen'i järgi, ja sa „tunned” seda luuletust sellisel moel, et sa ei osta teadmist luuletuse väe hinnaga. Väidan seda samas vaimus Walter Pateriga, kui too eitas Coleridge'i kuulsat orgaanilisuse analoogiat. ${ }^{24}$ Pateri arvates halvustas Coleridge (kui tahes tahtmatult) poeedi valu ja kannatusi luuletuse teoks tegemisel - kannatusi, mis vähemalt osaliselt sõltuvad mõjuängist ja mida ei saa luuletuse tähendusest eraldada.

Jorge Luis Borges, kommenteerides Blaise Pascali ülevat ja hirmsat tajumust oma Hirmuäratavast Sfäärist, võrdleb Pascali Giordano Brunoga, kes veel 1584. aastal võis juubeldada Mikołaj Koperniku revolutsiooni üle. Seitsekümmend aastat hiljem tuleb raugastumine - John Donne, Milton ja Joseph Glanvill näevad kõdu seal, kus Bruno rõõmustas mõtlemise edasiarenemise üle. Borges teeb järgmise kokkuvõtte: „Sellel rusutud sajandil muutus see absoluutne ruum, mis inspireeris Lucretiuse heksameetreid ning oli Brunole tähendanud vabanemist, Pascali jaoks labürindiks ja kuristikuks." Borges seda muudatust ei leina, kuna ka Pascal saavutab Üleva. Kuid tugevad poeedid ei eksisteeri erinevalt Pascalist selleks, et alistuda leinadele; nad ei saa sellega rahulduda, et Ülevuse eest tuleb nii kõrget hinda tasuda. Nagu Lucretius ise, valivad nad oma vabaduseks clinamen'i. Kuulakem siis Lucretiust:

Kui aatomid liiguvad oma kaalu mõjul läbi tühja ruumi otse alla, siis ettearvamatutel aegadel ning kohtadel kalduvad nad pisut oma kursilt kõrvale, nii vähe, et seda võiks pidada vaid suunamuudatuseks. Kui seda kõrvalekallet ei oleks, langeks kõik allapoole nagu vihmapiisad ilmaruumi kuristikus. Mingit kokkupõrget ei tekiks ning ükski aatom ei mõjutaks ühtegi teist. Nii poleks loodus iialgi midagi loonud...

Kuid õigupoolest ei ole vaimul endal mingit sisemist paratamatust, mis määrab iga tema tegu ning sunnib teda abitus passiivsuses kannatama - see on sellepärast, et aatomid kalduvad pisut kõrvale, kuid ettearvamatul ajal või kohas.

Kui mõtleme Lucretiuse clinamen'i üle järele, siis näeme Poeetilise Mõju viimset irooniat ning jõuame ringiga tagasi sinna, kus meie arutelu algas. Selle clinamen'i tugeva poeedi25 ja tema Poeetilise Isa vahel sooritab järeltulija-poeet kogu oma isiksuse jõudu maksma pannes ning modernse luule tõeline ajalugu koosneks nende revisionistlike kõrvalekallete täpsest kaardistamisest. Puhtale Patafüüsikule võiks mõni kõrvalekalle tunduda imeliselt suvalisena: Jarry ise oli võimeline Kristuse Kannatust vaatama kui ülesmäge jalgrattasõitu. Poeetilise Mõju õpilane on aga sunnitud olema ebapuhas Patafüüsik: ta peab mõistma, et clinamen'i

\footnotetext{
23 Jaanus Adamson kasutab siin eelkäija luuletuse asemel terminit „vanem-luuletus”.

24 Walter Pater (1839-1864) on inglise kirjandus- ja kunstikriitik.

25 Ikka eelistab Bloom siinkohal märkida tugevat poeeti (nagu eelnevalt ka efeebi) väikeste algustähtedega.
} 
peaks alati vaatlema ühtaegu taotlusliku ja mittetahtlikuna, ühtaegu iga poeedi Vaimse Kuju ning selle suvalise žestina, mille teeb iga poeet, kui tema langev keha põrkab vastu kuristiku põhja. Blake'i keeles on Poeetiline Mõju indiviidide liikumine läbi Seisundite, kuid see kulgemine tuleb neil halvasti välja, kui ei sooritata kõrvalekallet. Tugev poeet ütleb tõepoolest: "Mulle tundub, et mu langemine on lõppenud, nüüd olen langenud, seetõttu laman siin Põrgus." Kuid seda öeldes mõtleb ta: "Langemise käigus kaldusin kõrvale, seetõttu laman siin Põrgus, mille ise paremaks ümber lõin."

\section{Tõlkinud Tiina Kirss}

Tólke toimetanud Jaak Tomberg 